\title{
KUALITAS BIBIT MERAWAN (Hopea odorata Roxb.) ASAL KOFFCO SYSTEM PADA BERBAGAI UMUR
}

(Quality of Hopea odorata Roxb. Seedling from KOFFCO SYSTEM at Different Level of Age)*

\author{
Ahmad Junaedi ${ }^{1}$ dan/and Dodi Frianto ${ }^{1}$ \\ ${ }^{1}$ Balai Penelitian Teknologi Serat Tanaman Hutan \\ Jl. Raya Bangkinang-Kuok Km. 9, Bangkinang, Kampar, Riau, Telp. (0762) 7000121 Fax. (0762) 7000122 \\ email : ajunaedi81@yahoo.co.id \\ *Diterima: 02 Juni 2010; Disetujui: 07 Desember 2011
}

\begin{abstract}
This research was aimed to find out the planted readiness of merawan (Hopea odorata Roxb.) seedling from KOFFCO system according to age level of seedling. The research was undergoes through growth observation and physical quality assessment that was done to three age levels of Hopea odorata Roxb. Those are five months after planted (5 MAP), seven months after planted (7 MAP), and nine months after planted ( 9 $M A P)$. The observation and assessment was done to ten seedling samples of each age level which selected through simple randomized sampling method. The result showed that all growth and physical quality parameters of merawan seedling was signicantly influenced $(p<0,1)$ by age level of seedling. Refer to growth and physical quality magnitude, seedling will ready to planted at age nine MOAA with height higher than $20 \mathrm{~cm}$, shoot/root ratio about two and quality seedling index higher than 0,09.
\end{abstract}

Keywords: Merawan seedling, KOFFCO system, growth, physical quality, planted readiness

\begin{abstract}
ABSTRAK
Penelitian ini bertujuan untuk mendapatkan informasi umur bibit merawan (Hopea odorata Roxb.) asal KOFFCO system yang siap tanam berdasarkan pertumbuhan dan kualitas fisik bibit pada tiga tingkat umur yang dikaji. Penelitian dilakukan melalui pengamatan parameter pertumbuhan dan penilaian mutu fisik bibit merawan umur lima bulan setelah tanam (5 BST), tujuh bulan setelah tanam (7 BST), dan Sembilan bulan setelah tanam (9 BST). Pengamatan dan penilaian tersebut dilakukan terhadap 10 sampel bibit pada tiap tingkat umur bibit yang dipilih dengan metode simple random sampling. Hasil penelitian menunjukkan bahwa semua parameter pertumbuhan bibit merawan asal KOFFCO system dipengaruhi secara nyata $(\mathrm{p}<0,1)$ oleh tingkat umur. Berdasarkan besaran pertumbuhan dan mutu fisik bibit, bibit akan siap tanam pada umur sembilan BST. Pada umur tersebut tinggi bibit lebih dari $20 \mathrm{~cm}$, rasio pucuk akar (RPA) sama dengan dua dan IMB lebih dari 0,09.
\end{abstract}

Kata kunci: Bibit merawan, KOFFCO system, pertumbuhan, mutu fisik, siap tanam

\section{PENDAHULUAN}

Teknologi Komatsu Forda Fogging Cooling (KOFFCO) system telah digunakan untuk pembibitan merawan (Hopea odorata Roxb.) dengan hasil yang memuaskan. Berdasarkan laporan Sakai \& Subiakto (2007), melalui teknologi ini tingkat keberhasilan (persen berakar) jenis merawan (Hopea odorata Roxb.) cukup tinggi yaitu berkisar 83,5\% sampai 96,2\%. Hal ini didukung oleh Hidayat dan Nurohman (2007) yang menyatakan bahwa kemampuan berakar dan daya hi- dup stek merawan asal KOFFCO sytem sangat tinggi yaitu $90 \%$.

Teknologi KOFFCO system dipilih karena apabila mengandalkan teknik perbanyakan/pembibitan konvensional (perbanyakan dengan benih/generatif), kebutuhan terhadap bibit dalam jumlah yang banyak dan berkesinambungan akan relatif sulit dipenuhi. Hal ini disebabkan antara lain oleh karakteristik fenologi jenis yang tak berbunga sepanjang tahun, juga sifat bijinya yang rekalsitran (Badan Litbang Kehutanan dan Perkebunan, 1998). 
Adapun frekuensi pembungaan jenis ini diperkirakan berkisar antara tiga sampai empat tahun (Krishnapillay \& Tompsett, 1998).

Pada tahapan selanjutnya, untuk keperluan penanaman sebaiknya bibit merawan yang ditanam adalah bibit dengan kualitas yang baik. Hal ini penting dilakukan karena kualitas bibit merupakan awal yang akan menentukan kualitas hutan yang akan dibangun dan tegakan yang ada di dalamnya (Balai Teknologi Perbenihan, 1998). Kualitas hutan yang baik akan dapat diharapkan jika tegakan yang dibangun berasal dari bibit yang berkualitas tinggi secara genetika, fisik dan fisiologis.

Secara praktis informasi bibit yang berkualitas dapat diketahui dengan mengkuantifikasi/menilai parameter kualitas fisik bibit yaitu kekokohan, rasio pucuk akar (RPA) dan indeks mutu bibit (IMB). Penilaiannya dilakukan dengan mengamati parameter pertumbuhan bibit. Penilaian tersebut penting untuk dilakukan karena merupakan bagian yang akan turut diperhitungkan dalam rangka menentukan umur bibit layak tanam.

Kegiatan penilaian mutu fisik bibit merawan asal perbanyakan KOFFCO system belum banyak dilakukan. Salah satunya adalah penilaian mutu fisik bibit berdasarkan tingkat umur bibit. Akibatnya secara kuantitatif belum diperoleh data dan informasi umur bibit siap tanam.

Penelitian ini bertujuan untuk memperoleh data dan informasi umur bibit siap tanam pada bibit merawan (Hopea odorata Roxb.) asal perbanyakan KOFFCO system. Umur bibit siap tanam akan diperoleh berdasarkan pertumbuhan dan mutu fisik bibit pada tingkat umur yang dikaji.

\section{BAHAN DAN METODE}

\section{A. Waktu dan Lokasi Penelitian}

Penelitian dilaksanakan pada bulan April sampai dengan Juni 2007 di Perse266 maian Balai Penelitian Hutan Penghasil Serat (BPHPS) Kuok, Riau. Lokasi terletak pada ketinggian 52 meter di atas permukaan laut (dpl), dengan tipe iklim A menurut klasifikasi iklim Schmidt \& Ferguson (1951).

\section{B. Bahan dan Alat Penelitian}

Bahan yang digunakan pada penelitian ini adalah bibit merawan (Hopea odorata Roxb.) asal stek pucuk yang diperbanyak melalui KOFFCO system. Peralatan yang digunakan antara lain: alat ukur parameter pertumbuhan bibit, alat tulis, lux meter, oven, peralatan untuk membongkar bibit dan seperangkat komputer yang dilengkapi software SPSS 12 untuk analisis data.

\section{Metode Penelitian}

\section{Pengumpulan Data dan Penilaian Mutu Bibit}

Penilaian mutu fisik bibit Hopea odorata Roxb. asal perbanyakan KOFFCO system ini dilakukan terhadap bibit yang berumur lima bulan setelah tanam (5 BST), tujuh bulan setelah tanam (7 BST), dan sembilan bulan setelah tanam (9 BST). Penilaian dilakukan terhadap sepuluh sampel bibit pada tiga tingkat umur yang diambil secara acak (simple random sampling). Adapun tahapan penilaiannya adalah sebagai berikut :

a. Melakukan pengukuran tinggi dan diameter bibit.

b. Melakukan pengukuran terhadap berat kering bagian/organ bibit yaitu : berat kering akar (BKA), berat kering pucuk/batang dan daun (BKP) dan berat kering total bibit (BKT). Berat kering diperoleh dengan mengoven organ bibit pada suhu $105^{\circ} \mathrm{C}$ sampai beratnya konstan (sekitar 24 jam).

c. Hasil pengukuran pada tahap sebelumnya digunakan untuk mengkuantifikasi parameter mutu fisik bibit yaitu kekokohan, rasio pucuk akar (RPA) dan indeks mutu bibit (IMB). Formula yang digunakan adalah : 
1) Kekokohan $=\frac{\text { Tinggi }(\mathrm{cm})}{\text { Diamter }(\mathrm{mm})}$

(Hendromono, 2003)

2) $\mathrm{RPA} \quad=\frac{\text { Berat kering akar }(\mathrm{g})}{\text { Berat kering pucuk }(\mathrm{g})}$ (Hendromono, 2003)

3) $\mathrm{IMB}=\frac{\text { Berat kering total }(\mathrm{g})}{\text { RPA }+ \text { Kekokohan }}$

(Dickson et al., 1960 dalam Hendromono, 2003)

d. Bibit dinilai siap tanam apabila memenuhi kriteria berikut ini :

1) Tinggi bibit lebih dari $20 \mathrm{~cm}$ (Riyantoko,1999 dalam Srihadiono, 2005).

2) Nilai RPA ada pada kisaran 2-5 (Alrasyid, 1972 dalam Mindawati \& Yusnita, 2005).

3) Nilai IMB $\geq 0,09$ (Lackey \& Alm, 1982 dalam Hendromono, 2003).

4) Bibit dengan kekokohan lebih tinggi cenderung lebih layak untuk ditanam.

Pengamatan intensitas cahaya dan kandungan hara media bibit dilakukan untuk mengetahui parameter ekologi di sekitar tempat tumbuh bibit. Intensitas cahaya diukur selama tujuh hari pada jam pengamatan 09.00-16.00 WIB. Sementara itu, media tanam (top soil) dianalisis kandungan unsur haranya di laboratorium tanah Balai Pengkajian Teknologi Pertanian (BPTP) Riau. Variabel yang dianalisis adalah kandungan $\mathrm{C}$ dan $\mathrm{N}$ total dengan metode Kjeldahl; kandungan $\mathrm{P}_{2} \mathrm{O}_{5}, \mathrm{~K}_{2} \mathrm{O}$ dan $\mathrm{CaO}$ dengan metode penjenuhan amonium acetat $\mathrm{pH} 7$.

\section{Analisis Data}

Analisis statistik dilakukan untuk mengetahui tingkat validitas (kepercayaan) dari hasil penilaian mutu bibit yang dilakukan. Analisis pengaruh umur bibit terhadap kualitas bibit dilakukan melalui uji $\mathrm{F}$ dan uji lanjut Tukey dengan model ANOVA:

\footnotetext{
$Y i j=u+A i+E i j$

dimana :

Yij = Parameter pertumbuhan dan mutu fisik bibit pada umur bibit ke-i dan ulangan ke-j

$\mathrm{U}=$ rata-rata populasi

$\mathrm{Ai}=$ pengaruh umur bibit ke-i
}

Eij = Error pengaruh umur bibit ke-i dan ulangan ke-j.

Analisis kelayakan bibit siap tanam dilakukan melaui uji t satu sampel (one sample $t$ test) yaitu dengan membandingkan nilai tinggi bibit dengan nilai 20, RPA bibit dengan nilai RPA standar (dua atau lima) dan nilai IMB bibit dengan nilai IMB standar $(0,09)$.

\section{HASIL DAN PEMBAHASAN}

\section{A. Pertumbuhan Bibit}

Pertumbuhan bibit merupakan komponen penting yang akan menentukan kualitas fisik bibit. Komponen pertumbuhan bibit dapat dibagi menjadi dua bagian yaitu komponen pertumbuhan organ bibit di atas permukaan tanah yang dikenal sebagai pucuk/tajuk dan organ bibit di bawah permukaan tanah atau bagian perakaran. Sedangkan gabungan dari kedua komponen tersebut merupakan pertumbuhan keseluruhan bagian tanaman yang salah satunya dapat diwakili oleh berat kering total bibit (BKT). Pada penelitian ini paramater pertumbuhan komponen pucuk yang telah diamati meliputi tinggi, diameter dan berat kering pucuk bibit (BKP). Sedangkan parameter pertumbuhan komponen perakaran yang diamati adalah berat kering akar bibit (BKA).

Hasil uji $F$ terhadap variabel pertumbuhan tinggi dan diameter menunjukkan bahwa pada periode umur 5-9 bulan setelah tanam (BST), tinggi dan diameter merawan (Hopea odorata Roxb.) dipengaruhi secara nyata $(p<0,1)$ oleh tingkat umur. Hal ini menunjukkan bahwa pada rentang umur tersebut, laju pertumbuhan bibit masih signifikan.

Hasil uji lanjut dengan uji Tukey terhadap pertumbuhan tinggi bibit sebagaimana Gambar 1, menunjukkan bahwa tinggi bibit umur sembilan BST berbeda nyata dengan umur lima BST, tetapi tidak berbeda nyata dengan umur tujuh BST. Begitu pun tinggi bibit umur lima BST tidak berbeda nyata dengan umur tujuh 
BST. Hal ini mengindikasikan bahwa mulai umur lima BST, perbedaan umur bibit dua bulan tidak akan menye-babkan perbedaan pertumbuhan tinggi bibit yang nyata $(p<0,1)$. Perbedaan pertumbuhan bibit akan nyata $(\mathrm{p}<0,1)$, apabila perbedaan umur bibit empat bulan.

Hasil uji Tukey terhadap pertumbuhan diameter bibit sebagaimana Gambar 2, menunjukkan bahwa perbedaan diameter bibit yang nyata $(\mathrm{p}<0,1)$ hanya terjadi antara bibit lima BST dengan tujuh BST dan sembilan BST. Hal ini menunjukkan bahwa laju pertumbuhan diameter dua bulanan pada bibit Hopea odorata Roxb. masih nyata sampai umur tujuh BST. Akan tetapi di atas umur tujuh BST laju pertumbuhan diameter dua bulanannya sudah tidak nyata $(\mathrm{p}<0,1)$ lagi.

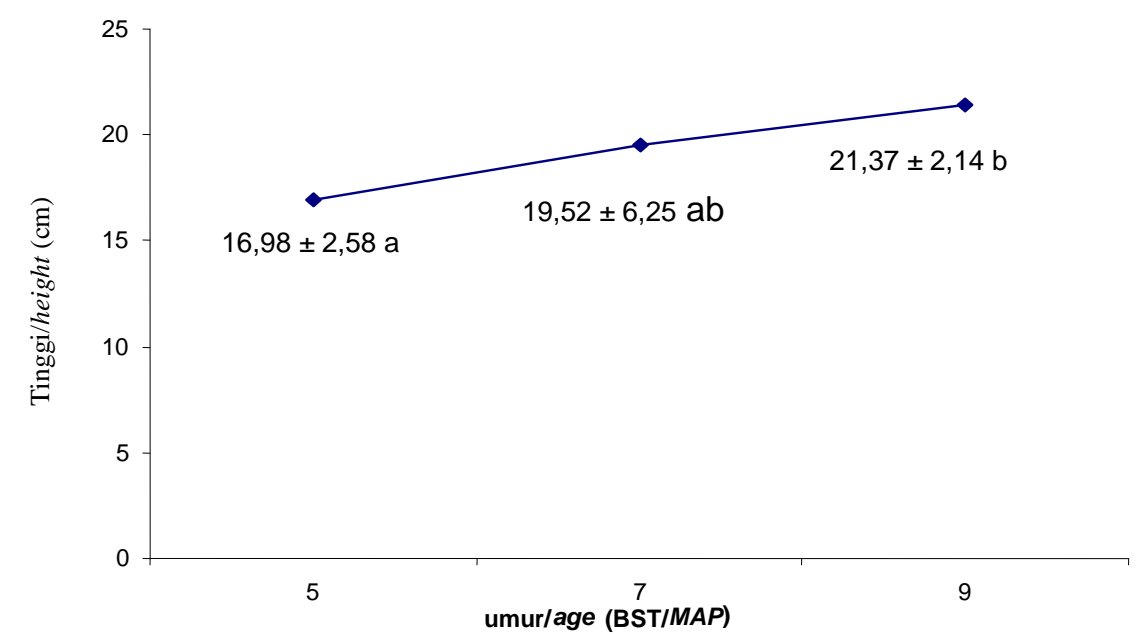

Gambar (Figure) 1. Pertumbuhan tinggi bibit Hopea odorata Roxb. pada berbagai tingkat umur (The height growth of Hopea odorata Roxb. seedling at different level of age)

Keterangan (Remarks):

BST/MAP = bulan setelah tanam (months after planted); angka yang diikuti huruf yang berbeda adalah berbeda nyata berdasarkan uji Tukey taraf 10\% (The numbers followed by different letters are significantly different at $10 \%$ level according to Tukey test)

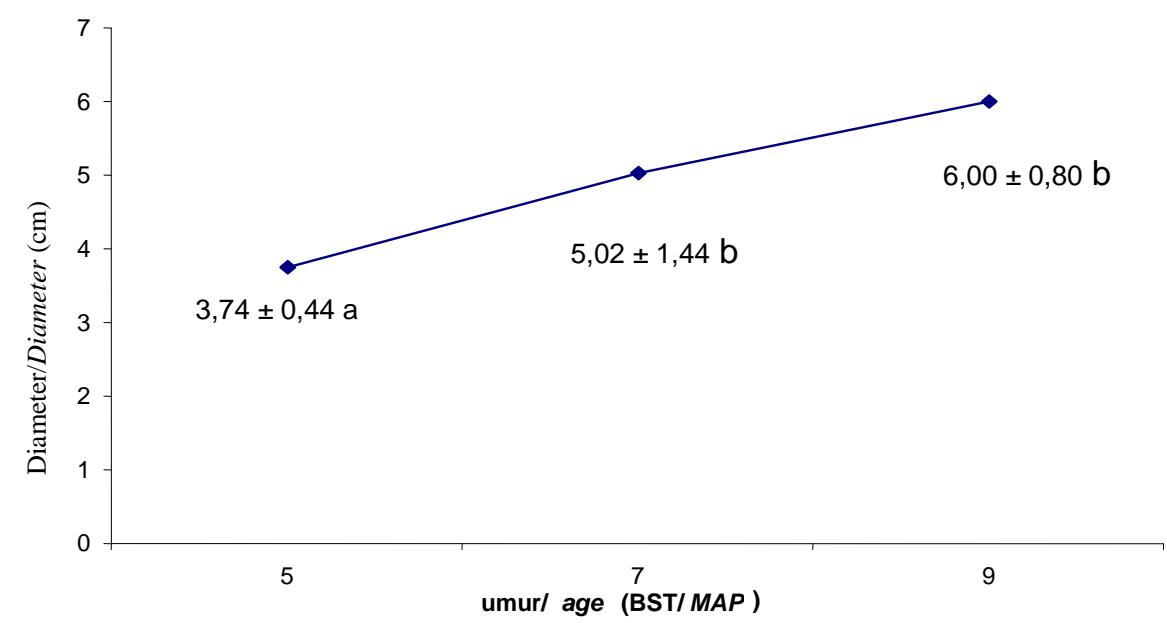

Gambar (Figure) 2. Pertumbuhan diameter bibit Hopea odorata Roxb. pada berbagai tingkat umur (The diameter growth of Hopea odorata Roxb. seedling at different level of age)

Keterangan (Remarks):

BST/MAP = bulan setelah tanam (months after planted); angka yang diikuti huruf yang berbeda adalah berbeda nyata berdasarkan uji Tukey taraf $10 \%$ (The numbers followed by different letters are significantly different at $10 \%$ level according to Tukey test) 
Hasil uji $\mathrm{F}$ terhadap berat kering komponen bibit menunjukkan bahwa berat kering komponen bibit secara nyata $(\mathrm{p}<0,1)$ dipengaruhi oleh tingkat umur bibit. Adapun berat kering komponen bibit pada umur sembilan BST adalah berat kering akar (BKA) 1,43 gram, berat kering pucuk (BKP) 2,88 gram dan berat kering totalnya 4,31 gram (Tabel 1).

Pertumbuhan bibit yang diekspresikan oleh tinggi, diameter dan berat kering komponen bibit (BKA, BKP dan BKT) pada dasarnya merupakan hasil dari akumulasi fotosintesis netto. Dengan demikian, adanya pengaruh nyata tingkat umur terhadap pertumbuhan bibit merawan umur 5-9 BST menunjukkan bahwa pada rentang umur tersebut laju fotosintesis bibit cenderung meningkat secara signifkan dengan bertambahnya umur. Hal ini dimungkinkan karena adanya kecukupan sumberdaya untuk kebutuhan fotosintesis di sekitar bibit. Sumberdaya yang dimaksud adalah cahaya matahari, air dan nutrisi/hara.
Cahaya merupakan salah satu bagian dari energi radiasi matahari yang letaknya pada kisaran spectrum 4-7 $\mu \mathrm{m}$ (Adnan \& Nasarudin, 2009). Dalam proses metabolisme tanaman (bibit) cahaya merupakan sumber energi utama bagi proses fotosintesis sehingga dikenal juga dengan istilah photosynthetic active radiation (PAR). Peran vital ini menyebabkan jumlahnya di sekitar tanaman akan turut mempengaruhi dinamika pertumbuhan.

Kuantitas cahaya yang diintersepsi bibit pada interval umur 5-9 BST menunjukkan persentase yang tidak berbeda nyata antar umur bibit (Tabel 2). Pada selang umur tersebut cahaya yang diintersepsi berkisar 82,1-84,2\%. Hal ini mengindikasikan bahwa pada rentang umur ini ketersediaan cahaya di sekitar bibit mencukupi untuk mendukung laju pertumbuhan bibit sehingga perbedaan umur dua bulan menyebabkan perbedaan pertumbuhan yang signifikan.

Tabel (Table) 1. Berat kering komponen bibit Hopea odorata Roxb. pada berbagai tingkat umur (The dry matter of Hopea odorata Roxb. seedling component at different level of age)

\begin{tabular}{clll}
\hline Umur bibit (age of seedling) & BKA/DWR (gr) & BKP/DWSh (gr) & BKT/DWSe(gr) \\
\hline U1 (5 BST/MAP) & $0,71 \pm 0,17 \mathrm{a}$ & $1,84 \pm 0,38 \mathrm{a}$ & $2,56 \pm 0,52 \mathrm{a}$ \\
U2 (7 BST/MAP) & $1,32 \pm 0,63 \mathrm{~b}$ & $2,13 \pm 0,98 \mathrm{a}$ & $3,45 \pm 1,52 \mathrm{ab}$ \\
U3 (9 BST/MAP) & $1,43 \pm 0,40 \mathrm{~b}$ & $2,88 \pm 0,64 \mathrm{~b}$ & $4,31 \pm 0,81 \mathrm{~b}$ \\
\hline
\end{tabular}

Keterangan (Remarks):

Angka yang diikuti hurup yang berbeda dalam satu kolom berbeda nyata berdasarkan uji Tukey taraf $10 \%$ (The numbers followed by different letters are significantly different at $10 \%$ level according to Tukey test); $\mathrm{BST} / M A P=$ bulan setelah tanam (months after planted); BKA/DWR = berat kering akar (dry weight of root); $\mathrm{BKP}=$ berat kering pucuk/DWSh (dry weight of shoot); BKT = berat kering total/DWSe (dry weight of seedling).

Tabel (Table) 2. Intersepsi cahaya matahari (\%) pada tiga tingkat umur bibit merawan (Sunlight interception percentage of Hopea odorata Roxb. at three level of seedling age)

\begin{tabular}{ccccc}
\hline No. & Umur/age & Io (lux) & Iin (lux) & Intersepsi cahaya/light interception (\%) \\
\hline 1 & 5 BST/MAP & 6068 & 1084 & $82,1 \pm 4,7 \mathrm{tn} /$ ns \\
2 & 7 BST/MAP & 7856 & 1357 & $82,7 \pm 2,7 \mathrm{tn} / n s$ \\
3 & 9 BST/MAP & 7748 & 1228 & $84,2 \pm 3,8 \mathrm{tn} / n s$ \\
\hline
\end{tabular}

Keterangan (Remarks):

$\mathrm{BST} / \mathrm{MAP}=$ bulan setelah tanam (months after planted); Io = intensitas cahaya di atas tajuk bibit/light intensity above seedling; Iin = intensitas cahaya di bawah tajuk bibit/light intensity below seedling; Intersepsi cahaya/light interception $=(1-(\mathrm{Iin} / \mathrm{Io})) \times 100 \%$; tn/ns $=$ tidak berbeda nyata berdasarkan uji F taraf $10 \%$ (not significantly different at $10 \%$ level according to $F$ test 
Selain cahaya, air dan nutrisi/hara merupakan sumberdaya penting yang turut mempengaruhi fotosintesis netto (pertumbuhan). Bersama gas karbon dioksida $\left(\mathrm{CO}_{2}\right)$, air $\left(\mathrm{H}_{2} \mathrm{O}\right)$ merupakan bahan baku (raw material) fotosintesis. Secara rutin penyiraman dilakukan dua kali sehari sehingga kebutuhan bibit terhadap air akan terpenuhi.

Ketersediaan unsur hara merupakan bagian yang penting untuk pertumbuhan tanaman (bibit). Beberapa hara atau nutrisi merupakan bagian penting yang menyusun sel/jaringan pada tanaman, misalnya nitrogen, magnesium dan besi $(\mathrm{Fe})$ sebagai penyusun klorofil (Abidin, 1984). Sementara beberapa unsur hara yang lainnya merupakan substansi pertumbuhan tanaman seperti unsur $\mathrm{P}$ dan $\mathrm{K}$ yang berperan dalam pertumbuhan diameter (Sambas 1979 dalam Herdiana et al., 2008a).

Kebutuhan nutrisi bibit selain diperoleh dari media tanam yakni top soil, juga diperoleh dari pupuk daun dosis lima g/ 15 liter yang rutin diberikan tiap 10 hari. Aplikasi pupuk daun tersebut akan menyebabkan pertumbuhan bibit lebih cepat
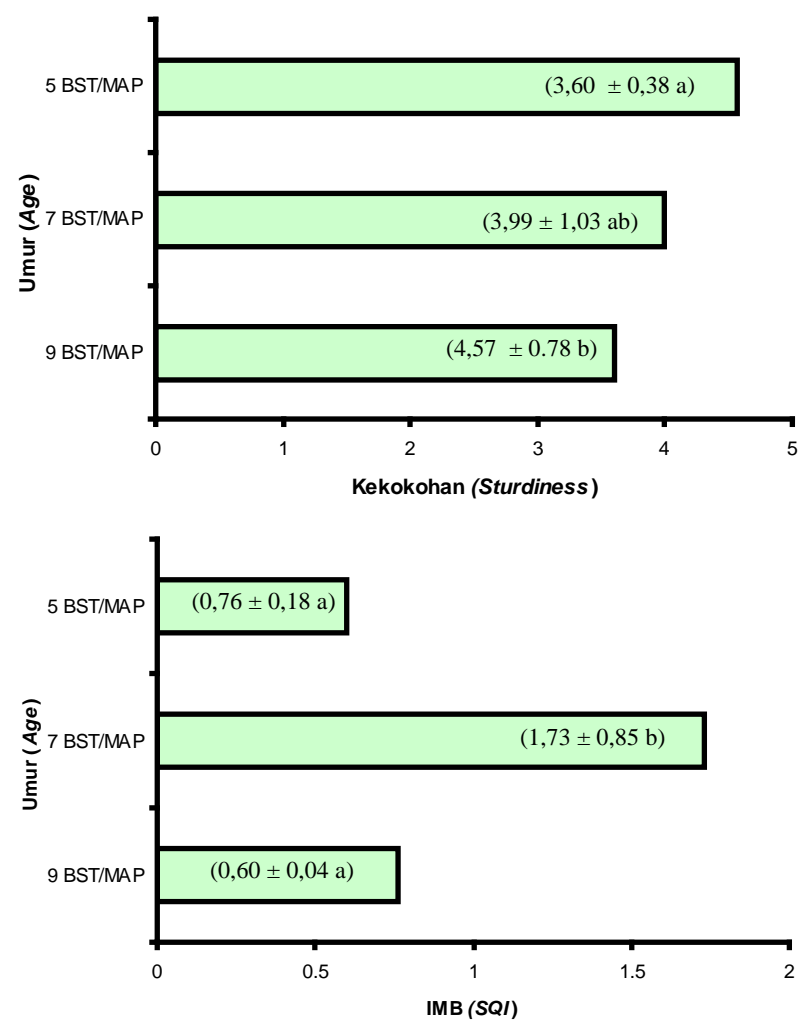

akibat karakteristik pupuk daun yang cenderung lebih cepat dan sempurna diserap tanaman (Rosmarkam \& Nasih, 2002). Hal ini sesuai dengan yang dilaporkan Herdiana et al. (2008b) yang menyatakan bahwa aplikasi pupuk daun dua g/liter tiap satu minggu secara nyata mampu meningkatkan pertumbuhan tinggi meranti belangeran dibandingkan kontrol.

\section{B. Mutu Fisik Bibit}

Hasil uji ANOVA menunjukkan bahwa semua parameter mutu fisik bibit merawan asal stek pucuk yaitu kekokohan, rasio pucuk akar/RPA dan indeks mutu bibit/IMB dipengaruhi secara nyata $(\mathrm{p}<0,1)$ oleh tingkat umur bibit. Ada kecenderungan nilai kekokohan bibit menurun seiring peningkatan umur bibit. Kekokohan tertinggi diperoleh pada umur bibit lima BST yakni 4,57. Sementara itu, variasi RPA dan IMB tidak konsisten mengikuti variasi tingkat umur bibit. RPA tertinggi diperoleh pada lima BST yaitu 2,61, sedangkan IMB tertinggi diperoleh pada umur tujuh BST yaitu 1,73 (Gambar 3 dan Gambar 4).

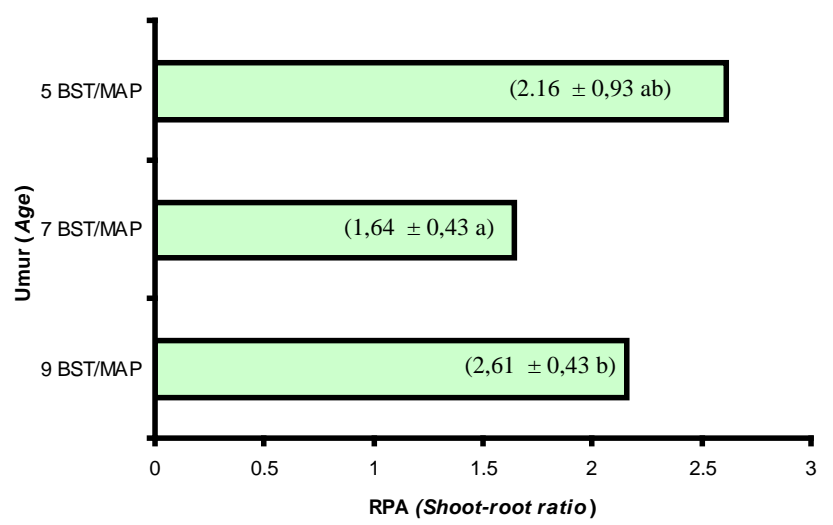

Gambar (Figure) 3. Variasi kekokohan, RPA, dan IMB bibit Hopea odorata Roxb. pada tiga tingkat umur (The Variation of sturdiness, shoot/root ratio, and seedling quality index of Hopea odorata_Roxb. at three levels of age)

Keterangan (Remarks) : BST/MAP = Bulan setelah tanam (months after planted); IMB/SQI = Indeks mutu bibit (Seedling Quality Index);angka yang diikuti huruf yang berbeda adalah berbeda nyata berdasarkan uji Tukey taraf $10 \%$ (The numbers followed by different letters are significantly different at $10 \%$ level according to Tukey test) 


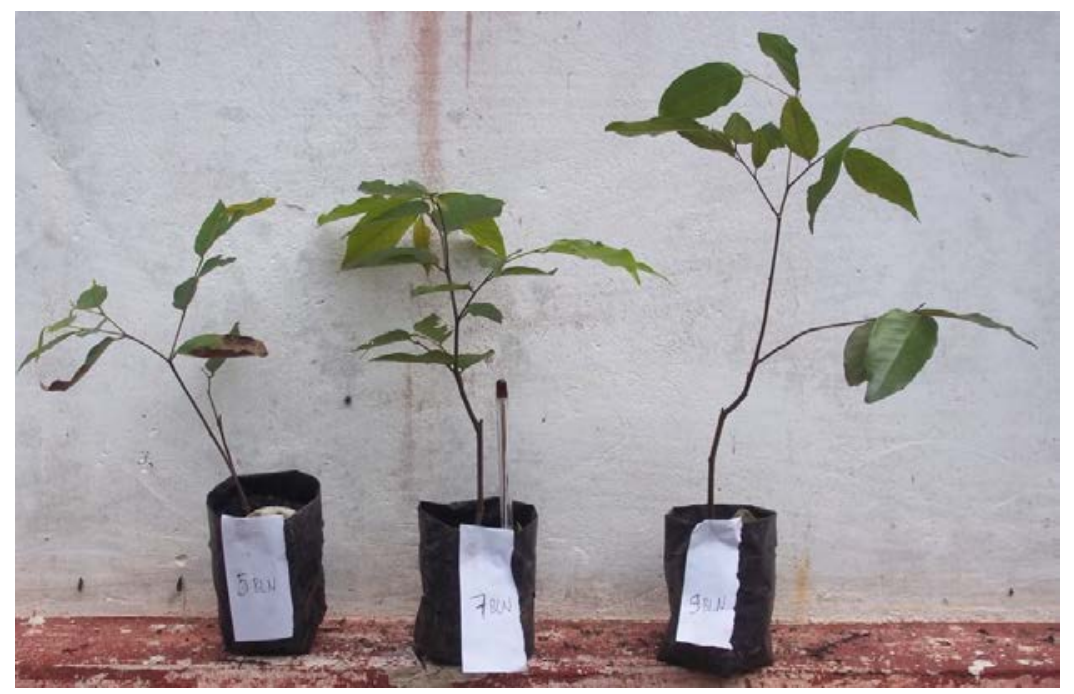

Gambar (Figure) 4. Bibit merawan (Hopea odorota Roxb.) asal KOFFCO system pada umur 5, 7, dan 9 bulan (Hopea odorata Roxb. seedling at 5, 7, and 9 months olds)

Penilaian kualitas fisik bibit, baik kekokohan, RPA, maupun IMB didasarkan kepada hasil kuantifikasi parameter-parameter pertumbuhan bibit. Dengan demikian maka besaran dan variasinya akan ditentukan oleh besaran dan variasi nilai parameter-parameter pertumbuhannya. Kekokohan bibit ditentukan oleh besaran dan variasi dari tinggi dan diameter bibit. RPA ditentukan oleh besaran dan variasi dari BKP dan BKA bibit, sedangkan IMB ditentukan oleh besaran dan variasi dari BKT, kekokohan, dan RPA bibit. Dengan demikian maka dapat dipahami bahwa mutu fisik bibit yang dipengaruhi nyata $(p<0,10)$ oleh tingkat umur dikarenakan pertumbuhannya yang juga dipengaruhi nyata oleh tingkat umur.

Durahim dan Hendromono (2006) melaporkan bahwa bibit eboni asal perbanyakan generatif (media topsoil + sabut kelapa) yang berumur sembilan bulan di persemaian memiliki kekokohan dan IMB berturut-turut 5,8 dan 0,18. Sementara itu, hasil penelitian ini menunjukkan bahwa pada umur yang sama (9 BST), bibit merawan asal stek pucuk memiliki nilai kekokohan yang lebih kecil yaitu 3,6, tetapi IMB-nya lebih tinggi yakni 0,76. Hal ini dimungkinkan karena selain perbedaan jenis tanaman dan teknik perba- nyakan, juga karena perbedaan media yang digunakan. Media yang digunakan pada bibit merawan yaitu top soil $100 \%$ akan memberikan input nutrisi tersedia yang cenderung lebih banyak dibanding media pada bibit eboni (top soil + sabut kelapa).

Beberapa nutrisi, di antaranya $\mathrm{P}$ (bentuk tersedia $\mathrm{HPO}_{4}{ }^{-}$dan $\mathrm{H}_{2} \mathrm{PO}_{4}{ }^{2-}$ ) dan $\mathrm{K}$ (bentuk tersedia $\mathrm{K}^{+}$) berperan penting dalam pertumbuhan diameter dan perakaran (Salisbury \& Ross, 1995; Sambas, 1979 dalam Herdiana et al., 2008a). Dengan demikian, kuantitasnya yang diduga lebih banyak pada media bibit merawan dibandingkan pada media bibit eboni akan menyebabkan pertumbuhan diameter dan perakaran bibit merawan yang lebih baik (Tabel 3). Pertumbuhan diameter yang lebih besar terhadap tinggi akan menyebabkan nilai kekokohan bibit merawan menjadi lebih kecil. Peningkatan pertumbuhan akar diekspresikan oleh BKA akan meningkatkan IMB. Akibatnya, pertumbuhan akar yang lebih baik pada bibit merawan akan menyebabkan nilai IMB-nya lebih tinggi dibandingkan IMB eboni.

Hendalastuti dan Hidayat (2004) melaporkan bahwa pada umur lima bulan, nilai RPA bibit Gmelina arborea yang 
Tabel (Table) 3. Sifat kimia media tanam pada bibit merawan (Chemical properties of merawan seedling media)

\begin{tabular}{clc}
\hline No. & \multicolumn{1}{c}{$\begin{array}{c}\text { Jenis unsur hara } \\
\text { (Nutrients) }\end{array}$} & Nilai (Value) \\
\hline 1 & Nitrogen (\%) & 0.39 \\
2 & P-bray (ppm ) & 21,84 \\
3 & C-organik (\%) & 4,65 \\
4 & Ca (me/100 gr) & 1,51 \\
5 & K (me/100 gr) & 0,61 \\
6 & KTK (me/100 gr) & 15,02 \\
\hline
\end{tabular}

diberi asam humat konsentrasi 1800 ppm adalah 2,06. Pada umur yang sama yakni lima BST, nilai tersebut lebih kecil dibandingkan RPA bibit merawan asal stek pucuk yaitu 2,61. RPA yang lebih kecil mengindikasikan pertumbuhan perakaran yang lebih baik, yang berarti pertumbuhan akar bibit Gmelina arborea yang dilaporkan lebih baik dibandingkan akar bibit merawan yang diteliti. Hal ini disebabkan karena asam humat yang ada pada media bibit Gmelina arborea berperan dalam melepaskan phosfor $(\mathrm{P})$ yang terjerap dalam tanah menjadi $\mathrm{P}$ tersedia bagi bibit (Sofyan et al., 2007). Ketersediaan unsur $\mathrm{P}$ tersebut menjadikan perakaran bibit tumbuh lebih baik.

\section{Kelayakan Bibit Siap Tanam}

Penilaian kelayakan bibit siap tanam secara utuh harus memperhitungkan mutu fisik, fisiologis dan genetik. Akan tetapi, dalam prakteknya diperlukan metode yang tidak sederhana dan waktu yang tidak singkat. Padahal dalam menilai kelayakan bibit siap tanam, di antaranya harus menggunakan metode yang relatif sederhana dan dilakukan dengan cepat (Nurhasybi dan Sudrajat, 2006). Cara yang dianggap relatif sederhana, cepat dan hasilnya masih dipercaya adalah berdasarkan penampilan fisik bibit. Dengan pertimbangan tersebut untuk menilai kelayakan bibit siap tanam didasarkan pada penampilan fisiknya yaitu tinggi tanaman, RPA dam IMB.

Bedasarkan penampilan morfologinya bibit dikategorikan siap tanam jika memenuhi persyaratan tinggi bibit lebih dari $20 \mathrm{~cm}$ (Riyantoko,1999 dalam Srihadiono, 2005), RPA berada pada kisaran 25 (Alrasyid, 1972 dalam Mindawati dan Yusnita, 2005), dan IMB di atas 0,09 (Lackey dan Alm, 1982 dalam Durahim dan Hendromono, 2006). Hasil uji t menunjukkan bahwa hanya umur bibit sembilan BST yang memenuhi semua persyaratan tersebut. Pada umur tersebut tinggi bibit merawan secara nyata $(\mathrm{p}<0,1)$ lebih tinggi dari $20 \mathrm{~cm}$, RPA ada pada kisaran 2-5 dan IMB lebih tinggi dari 0,09. Umur lima BST tidak memenuhi persyaratan karena tingginya masih lebih rendah dari $20 \mathrm{~cm}$. Sementara umur tujuh BST pun tidak memenuhi persyaratan karena selain RPAnya lebih kecil dari dua, juga tingginya belum mencapai lebih dari $20 \mathrm{~cm}$.

Hasil tersebut menunjukkan bahwa dengan menggunakan teknik pemeliharaan bibit yang selama ini dilakukan, ternyata diperlukan waktu sembilan bulan untuk mencapai bibit siap tanam. Pada tahapan aplikasi, waktu sembilan bulan merupakan waktu yang cukup lama sehingga diperlukan teknik pemeliharaan yang dapat mempersingkat umur bibit siap tanam. Teknik pemeliharaan yang bisa dipilih antara lain adalah dengan meningkatkan dosis dan frekuensi pemberian pupuk daun, penggunaan asam humat dan penambahan kompos pada media tanam bibit.

\section{KESIMPULAN DAN SARAN}

\section{A. Kesimpulan}

1. Tingkat umur bibit pada kisaran lima sampai sembilan bulan setelah tanam, berpengaruh secara signifikan terhadap pertumbuhan dan mutu fisik bibit merawan asal KOFFCO system.

2. Bibit merawan asal KOFFCO system akan siap ditanam di lapangan pada umur sembilan bulan setelah tanam.

\section{B. Saran}

Untuk mempersingkat umur bibit siap tanam diperlukan perbaikan teknik 
pemeliharaan di antaranya dengan memperbaiki media tanam dan teknik pemupukan.

\section{DAFTAR PUSTAKA}

Abidin, Z. (1984). Ilmu tanaman. Bandung: Angkasa.

Adnan, \& Nasaruddin. (2009). Kloroplas dan fotosintesis. Diunduh 13 Januari 2010 dari http://www.scribed .com.

Badan Litbang Kehutanan dan Perkebunan. (1998). Sinopsis hasil-hasil penelitian kehutanan. Jakarta: Badan Litbang Kehutanan dan Perkebunan.

Balai Teknologi Perbenihan. (1998). Program nasional sistem perbenihan kehutanan. (Publikasi Khusus). Bogor: Balai Teknologi Perbenihan.

Durahim, \& Hendromono. (2006). Pengaruh media dan pupuk NPK terhadap pertumbuhan dan mutu bibit eboni. Jurnal Penelitian Hutan dan Konservasi Alam, 3(1),9-17.

Hendalastuti, H., \& Hidayat, A. (2004). Peran asam humat dan asam oksalat dalam peningkatan pertumbuhan tanaman keras Gmelina arborea. Jurnal Biologika, 1(10), 46-59.

Hendromono. (2003). Kriteria peniliaian mutu bibit dalam wadah yang siap tanam untuk rehabilitasi hutan dan lahan. Buletin Penelitian dan $\mathrm{Pe}$ ngembangan Kehutanan, 4(1), 1120.

Herdiana, N., Siahaan, H., \& Rahman, T. (2008a). Pengaruh arang kompos dan intensitas cahaya terhadap pertumbuhan kayu bawang. Jurnal Penelitian Hutan Tanaman,5(3), 139146.

Herdiana, N., Lukman, A. H., Mulyadi, K., \& Suhendar, T. (2008b). Pengaruh konsentrasi dan frekuensi aplikasi pupuk daun terhadap pertumbuhan bibit meranti belangeran asal cabutan alam di persemaian. Jurnal
Penelitian Hutan Tanaman, 5(3), 147-154.

Hidayat, A., Hendalastuti, H., \& Nurrohman, E. (2007). Pengaruh ukuran diameter stek batang Hopea odorata Roxb. dari kebun pangkas terhadap kemampuan bertunas, berakar dan daya hidupnya. Jurnal Penelitian Hutan dan Konservasi Alam, 4(1),1-12.

Krishnapillay, \& Tompsett, P. B. (1998). Seed handling: A review of Dipterocarps : taxonomy, ecology, and silvyculture (pp.73-88). Bogor: CIFOR.

Mindawati, N., \& Yusnita, S. (2005). Pengaruh macam media terhadap pertumbuhan semai Acacia mangium Willd. Jurnal Penelitian Hutan dan Konservasi Alam, 2(1),53-59.

Nurhasybi, \& Sudradjat, P. J. (2006). Bagaimana mutu bibit tanaman hutan yang ideal? Tinjauan singkat untuk pengadaan bibit bermutu. Prosiding Seminar Hasil-hasil Penelitian Balai Litbang Teknologi Perbenihan di Bogor Tanggal 14 Pebruari 2006 (pp.179 -183). Bogor: Pusat Penelitian dan Pengembangan Hutan Tanaman.

Rosmarkam, A., \& Nasih, W. Y. (2002). Ilmu kesuburan tanah. Yogyakarta: Kanisius.

Sakai, C., \& Subiakto, A. (2007). Pedoman pembuatan stek jenis-jenis dipterokarpa dengan KOFFCO sistem. Bogor: Pusat Penelitian dan Pengembangan Hutan dan Konservasi Alam.

Salisbury, F. B., \& Ross, C.W. (1995). Fisiologi Tumbuha. Jilid 1. (R.L. Diah, dan Sumaryono, Terjemahan). Bandung: Institut Teknologi Bandung.

Schmidt, F. H., \& Ferguson, J. H. A. (1951). Rainfall typed based on wet and dry period ratios for Indonesia with western New Guinea (Verhand No.42). Jakarta: Direktorat Meteorologi \& Geofísika. 
Sofyan, E. T., Mulyani, O., \& Sandrawati, A. (2007). Pengaruh kompos sampah kota dan pupuk kandang domba terhadap beberapa sifat kimia tanah dan hasil tanaman jagung manis pada Fluventic Eutrudepts asal Jatinangor Sumedang

(Laporan Penelitian). Diunduh 14 Nopember 2010 dari www .pustakaunpad.ac.id.

Srihadiono, U. S. (2005). HTI : Skenario masa depan kehutanan Indonesia. Palembang: PT. Musi Hutan Persada dan Wana Aksara. 